\title{
Panthera tigris: range and population collapse in Northern West Bengal, India
}

\begin{abstract}
During the last two centuries, tiger population has been extirpated from about $1,000 \mathrm{~km}^{2}$ of its historic range in Northern West Bengal and dwindled at an alarming rate in their last refuse, i.e. the protected areas, spread over $>1,000 \mathrm{~km}^{2}$, due to increasing anthropogenic pressures and other reasons. Intra-state and inter-state migration of the tigers, usually on a seasonal basis, is also reported from these protected areas, leading to very much lower population than in ecologically comparable sites in India.
\end{abstract}

Keywords: sporadic distribution, habitat viability, seasonal migration, population fluctuation
Volume 3 Issue 3 - 2019

Jayanta Kumar Mallick

Wildlife Wing, Forest Directorate, Government of West Bengal, India

Correspondence: Jayantha Kumar Mallick, Wildlife Wing (Headquarters), Forest Directorate, Government of West Bengal, Bikash Bhawan, North Block, 3rdfloor, Salt Lake City, Kolkata, 70009I, India, Email jayantamallick2007@rediffmail.com

Received: April 17, 2019 | Published: May 10, 2019

\section{Introduction}

The Indian Tiger, Panthera tigris Linnaeus, 1758 (Carnivora: Felidae), is now confined to two isolated and disjunct (broken by $>700 \mathrm{~km}$ ) habitats of West Bengal. ${ }^{1}$

Northern region: The river Teesta has divided the region into two parts- (a) terai or sub-Himalayan lowland, characterised by tall grasslands, scrub savannah, sal forests and clay-rich swamps and (b) western dooars or duars, the alluvial floodplains with savanna grasslands and foothills of the eastern Himalayas, which is the gateway to the North-East India and Bhutan (the hilly region of Darjeeling and the swamps of plains, south of terai and dooars up to the left bank of the Ganges, known as 'Tal', 'Barind' and 'Diara', being erstwhile habitats), Southern region: mangrove swamps of Sundarbans, the largest in the State (beyond the purview of this article). During the $19^{\text {th }}$ and $20^{\text {th }}$ century, the land-use pattern in North Bengal was changed radically with spread of (i) agriculture, (ii) establishment of hundreds of tea gardens (since 1835), including the shut down and sick ones, where more than 1.1 million people, mostly forest-dependent, live in, (iii) conversion of forest land to army cantonments, (iv) diversion of forestland for railways and highways, etc. These changes have gradually made the forest highly fragmented.

Under the circumstances, Protected Areas (PAs), in which nonforestry human occupation or activities, at least the exploitation of resources is limited, are vital for conservation of biodiversity including the umbrella species 'tiger', considering that this top predator controls the population and distribution of its primary prey animals (specially the ungulates, which are prolific breeders), which in turn will revive the forest composition, structures, and regeneration. Hence, population collapse would enhance demise of thousands of other associated species and invite environmental hazards. In practice, tiger conservation in the study area continues to face increasing challenges for the PA managers. Up to $19^{\text {th }}$ century, tiger population was abundant in the northern region, but declining sharply (demographic collapse) due to extensive habitat loss, degradation, encroachment, prey depletion due to shortage of fodder for wild herbivores, man-animal conflict, poaching, illegal wildlife trade, besides developmental activities like construction of roads and railway lines including conversion of meter gauge to broad gauge, unrestricted tourism and lack of efficiency in park management and protection infrastructure. On the other hand, such isolation and very small size of tiger population in the PAs and the resultant lack of genetic diversity may lead to extinction of the species in the study area.

The status of wild tigers in northern West Bengal was first studied in 2009. ${ }^{2}$ During the last one decade, this umbrella species has reportedly been suffering from tremendous biotic pressure even in the national parks, wildlife sanctuaries and tiger reserve, known to harbor the species $\left(>1,000 \mathrm{~km}^{2}\right)$. The forest department has arranged for status survey through genetic analysis of faecal samples of tiger since 2010 and generating new figures of tiger population in a selected PA. In addition, camera trap survey in a capture-recapture framework has also been introduced in the region since 2015. In the absence of any further published material on a regional-level plight of tiger during the last one decade, this study was undertaken with a view to filling this knowledge gap.

\section{Study area}

The study area (Figure 1) is located along four mountain ranges (Singalila, Donkhya or Darjeeling-Kurseong, Chola and Sinchula) and the foothills of the eastern Himalayas, where the majority of the state's protected area network (important biological conservation areas including critical tiger habitats and intervening wildlife corridors) is situated and these fragmented habitats are bounded by Nepal $(50 \mathrm{~km}$ road from Manebhanjyang to Phalut) on the west, Sikkim and Bhutan on the north, Assam on the east and Bangladesh on the south.

The study area (Geographical area:22,054km²; Forest area: $\left.3031.03162 \mathrm{~km}^{2}\right)$ is under eight districts as follows:

1. Darjeeling [Geographical area:2,092.5 $\mathrm{km}^{2} \quad\left(27^{\circ} 01^{\prime} 48.00^{\prime \prime} \mathrm{N}\right.$, $\left.88^{\circ} 09^{\prime} 36.00^{\prime \prime} \mathrm{E}\right)$; Forest area:710.4164km²],

2. Kalimpong [Geographical area: $1,053.60 \mathrm{~km}^{2}\left(27^{\circ} 03^{\prime} 36.00^{\prime \prime} \mathrm{N}\right.$, $\left.88^{\circ} 28^{\prime} 12.00^{\prime \prime} \mathrm{E}\right)$; Forest area:532.7683 $\left.\mathrm{km}^{2}\right]$,

3. Jalpaiguri [Geographical area: $3,044 \mathrm{~km}^{2}\left(26^{\circ} 16^{\prime}-27^{\circ} 0^{\prime} \mathrm{N}, 88^{\circ} 4^{\prime}-\right.$ $\left.89^{\circ} 53^{\prime} \mathrm{E}\right)$; Forest area: $\left.628.75522 \mathrm{~km}^{2}\right]$,

4. Alipurduar [Geographical area:3,383 $\mathrm{km}^{2}\left(26^{\circ} 4^{\prime}-26^{\circ} 83^{\prime} \mathrm{N}, 89^{\circ} 0^{\prime}-\right.$ $\left.89^{\circ} 9^{\prime} \mathrm{E}\right)$; Forest area:694.2663km²], 
5. Koch Behar [Geographical area:3,387 $\mathrm{km}^{2} \quad\left(26^{\circ} 19^{\prime} 27.08^{\prime} \mathrm{N}\right.$ $89^{\circ} 27^{\prime} 3.71$ 'E); Forest area:66.5538km²],

6. Malda [Geographical area: $3,733 \mathrm{~km}^{2} \quad\left(25^{\circ} 00^{\prime} 0.00^{\prime} \mathrm{N}\right.$, $\left.88^{\circ} 09^{\prime} 0.00^{\prime \prime} \mathrm{E}\right)$; Forest area: $\left.17.02045 \mathrm{~km}^{2}\right]$,

7. Uttar (North) Dinajpur [Geographical area:3,142 $\mathrm{km}^{2}\left(25^{\circ} 36^{\prime} 50.40^{\prime \prime} \mathrm{N}, \quad 88^{\circ} 07^{\prime} 33.60\right.$ ”'E); $\quad$ Forest area: $\left.6.02379 \mathrm{~km}^{2}\right]$.

8. Dakshin (South) Dinajpur [Geographical area:2,219km² $\left(25^{\circ} 13^{\prime} 12.00^{\prime \prime} \mathrm{N} 88^{\circ} 45^{\prime} 36.00^{\prime} \mathrm{E}\right)$; Forest area:8.27426km²].

The study area comprises twelve territorial Forest and Wildlife Divisions, including notified PAs [National Park (NP); Wildlife Sanctuary (WLS)], as specified against each district.

1. Darjeeling: $267.6687 \mathrm{~km} 2$ (fragmented), Kurseong: $163.5277 \mathrm{~km} 2$ (fragmented), Wildlife I: $279.22 \mathrm{~km} 2$ [Singalila NP:78.60km², buffer: $30.7 \mathrm{~km} 2$; altitude $2,200-3,636 \mathrm{~m}\left(26^{\circ} 31-27^{\circ} 31 \mathrm{~N}, 8^{\circ} 59^{\prime}\right.$ $\left.88^{\circ} 53^{\prime} \mathrm{E}\right)$, Panchthar-Ilam-Taplejung Corridor of Nepal forming a contiguous forest connected to the Singalila and used by the Red Panda and other wildlife], Senchal WLS [38.88 km², 1067$\left.2600 \mathrm{~m}\left(26^{*} 56^{\prime} \mathrm{N}-27^{*} 00^{\prime} \mathrm{N}, 88^{*} 18^{\prime} \mathrm{E}-88^{*} 20^{\prime} \mathrm{E}\right)\right]$, Mahananda WLS $\left[158.04 \mathrm{~km}^{2}, 200-1000 \mathrm{~m}\right.$ (265' $33^{\prime \prime}-26^{\circ} 47^{\prime} 54^{\prime \prime} \mathrm{N}$, $\left.\left.88^{\circ} 33^{\prime} 31^{\prime \prime}-88^{\circ} 23^{\prime} 36^{\prime \prime} \mathrm{E}\right)\right]$, Jorepokhri WLS [0.04km², $2300 \mathrm{~m}$ $\left.\left(26^{\circ} 70^{\prime}-26^{\circ} 79^{\prime}, 88^{\circ} 21^{\prime}-88^{\circ} 31^{\prime}\right)\right]$;
2. Kalimpong: $372.8766 \mathrm{~km}^{2}$ (fragmented), Wildlife II: Neora

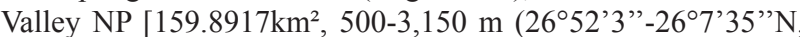
$\left.\left.88^{\circ} 45^{\prime}-88^{\circ} 55^{\prime} \mathrm{E}\right)\right]$

3. Jalpaiguri: $310.88 \mathrm{~km}^{2}$ (fragmented), Baikunthapur: $228.82522 \mathrm{~km}^{2}$ (fragmented), Wildlife II:Gorumara NP [79.45 $\mathrm{km}^{2}$

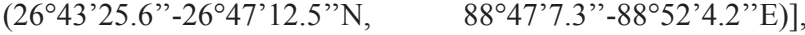
Chapramari WLS $\left(9.60 \mathrm{~km}^{2}\right)$;

4. Alipurduar:Wildlife III: Jaldapara (other than NP):90.1587 $\mathrm{km}^{2}$, NP $\quad\left[216.34 \mathrm{~km}^{2} \quad\left(25^{\circ} 58^{\prime \prime}-27^{\circ} 45^{\prime \prime} \mathrm{N}, \quad 89^{\circ} 08^{\prime \prime}-89^{\circ} 55^{\prime \prime} \mathrm{E}\right)\right]$, Buxa Tiger Reserve [BTR: 60-1,750 m $\left(26^{\circ} 30^{\prime}-26^{\circ} 55^{\prime} \mathrm{N}\right.$, $\left.89^{\circ} 20^{\prime}-89^{\circ} 55^{\prime} \mathrm{E}\right)$ ]: East: 387.7676 [Buffer $\left(112.9364 \mathrm{~km}^{2}\right)$, PA $\left.\left(274.8312 \mathrm{~km}^{2}\right)\right]$; West: $366.9531\left[\right.$ Buffer $\left(257.4758 \mathrm{~km}^{2}\right)$, PA $\left.\left(109.4773 \mathrm{~km}^{2}\right)\right]$

5. Koch Behar (fragmented): No PA;

6. Malda (fragmented): No PA;

7. Uttar Dinajpur (fragmented): Raiganj WLS $\left(1.3 \mathrm{~km}^{2}, 25^{\circ} 37^{\prime} \mathrm{N}\right.$, $88^{\circ} 12^{\prime} \mathrm{E}$ ), not a suitable tiger habitat; and

8. Dakshin Dinajpur (fragmented): No PA.

There are some active biological corridors linking the PAs of Kalimpong and Alipurduar districts and those of Sikkim, Assam and Western Bhutan.

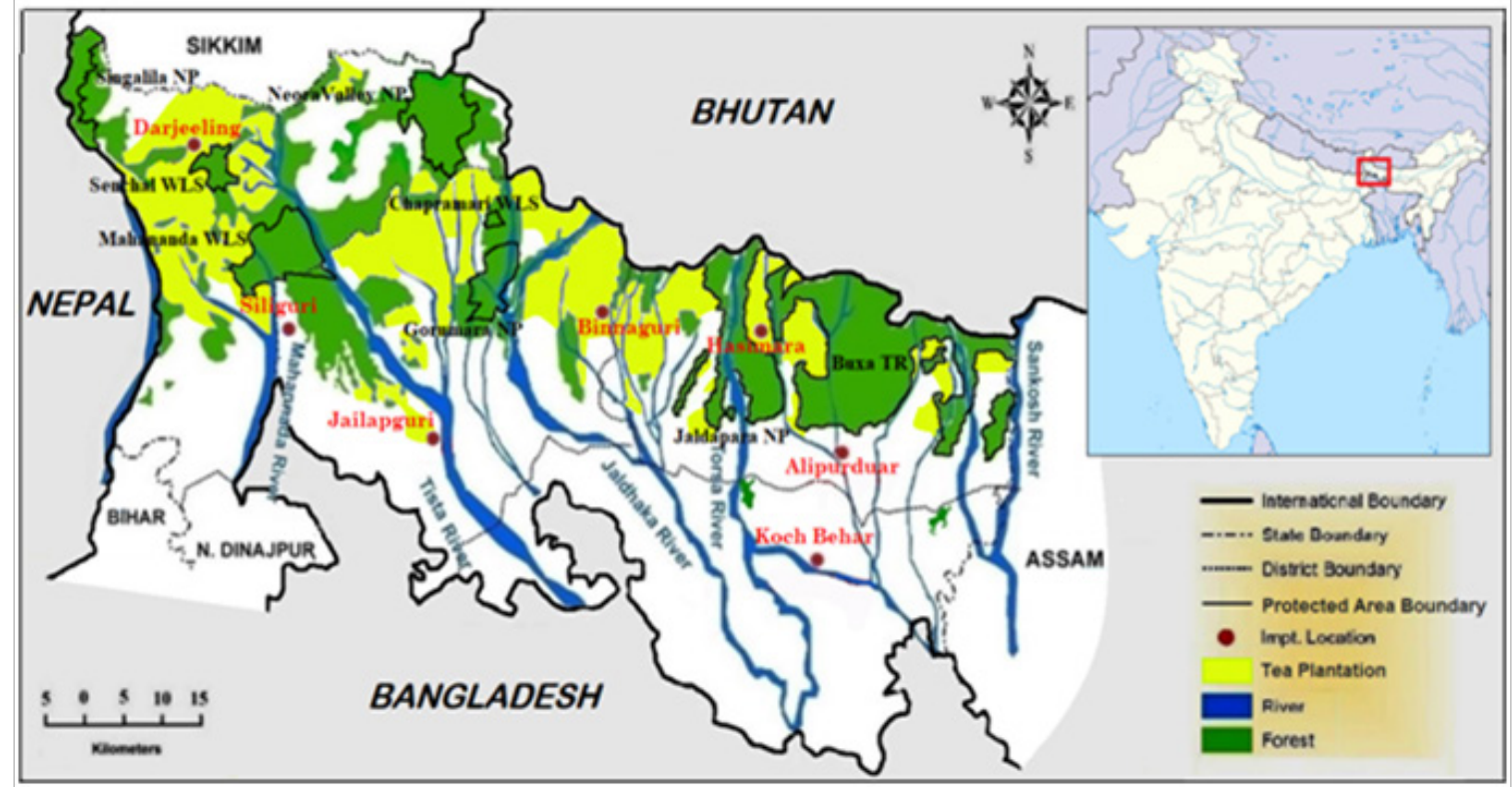

Figure I The study area.

\section{Methodology}

The primary data were collected through field observations during three consecutive seasons and open-ended questionnaire. Using this questionnaire, the forest village heads (Mandals), members of Eco-development and Forest Protection Committees, and forest dependent fringe people, selected by using a stratified random sampling technique, were interviewed in addition to the forest department officials. Secondary data were collected from published and unpublished reports, research papers and articles.

\section{Results and discussion}

A wide variety of physical and climatic features have resulted in a diversity of ecological habitats in northern West Bengal, some of which are known to form traditional range of the tiger. Up to early $20^{\text {th }}$ century, it used to occur in high altitude, terai or foothills, and 
even plains as long as it could hunt enough prey species, mainly ungulates, bovids, suids, to feed on and a secured habitat for breeding. It is, however, assumed that during the last two centuries, tiger population has been extirpated from about $1,000 \mathrm{~km}^{2}$ of its historic range in northern West Bengal (entire Malda, Dinajpur and Koch Behar districts as well as most of Darjeeling, Kalimpong, Jalpaiguri and Alipurduar districts) due to biotic and abiotic factors. Compared to a population range $8-12,{ }^{3}$ the 2014 assessment has recorded only 3 tigers in this region. ${ }^{4}$ Specific locations were not mentioned in these records. No figure has, however, been mentioned in $2010 .{ }^{5}$ While tiger occupancy in entire North Bengal was assessed to be $596 \mathrm{~km}^{2}$ in 2006 and $799 \mathrm{~km}^{2}$ (increased by about $200 \mathrm{~km}^{2}$ ) in $2010 .{ }^{5}$

In the present study, sporadic distribution of tigers has been recorded even in the PAs. Moreover, in spite of habitat viability in a few protected areas, the tigers are found either absent (e.g. Gorumara or Mahananda) or at exceedingly low numbers (for example, BTR in spite of its higher carrying capacity). On the whole, the species is facing extinction threshold in the traditional rangeland of the region. In the study area, the forests consist of a few conifers at high altitude on the north in Darjeeling with belts of rhododendrons. The oak, champ and magnolias flourish lower down. At present, this region is not a suitable tiger habitat because of inadequate prey population and anthropogenic pressures. Even during early $20^{\text {th }}$ century, the tiger was common in terai because the habitat was well stocked with prey animals, when tiger was met with in large numbers in the plains as well as lower hills up to $610 \mathrm{~m}$ and, in a few instances, in the upper hills up to 2,134 m altitude. ${ }^{6}$ Tiger pug-marks were observed on the elephant tracks at $2,438 \mathrm{~m}$ altitude. ${ }^{7}$ Occasionally, the tiger has been known to successfully pick off a young elephant distracted away from the protection of the herd. Tiger was occasionally sighted in Singalila NP (Figure 2). During early twentieth century, tigers were sighted up to an altitude of $3,200 \mathrm{~m}$ in two sites, ${ }^{8}$ both surrounded by rhododendron forests, located at a distance of $15 \mathrm{~km}$. It was sighted in Eastern Himalayan sub-alpine conifer forests (temperate biome) of Tonglu $\left(25.08 \mathrm{~km}^{2}, 3,070 \mathrm{~m}, 27.03^{\circ} \mathrm{N} 88.09^{\circ} \mathrm{E}\right)$ and at Kalpokhri $\left(3186 \mathrm{~m}, 27.04^{\circ} \mathrm{N} 88.00^{\circ} \mathrm{E}\right)$, meaning 'Dark lake', where the water never freezes. There are about 45 forest villages (Khasmahal) in the periphery of the park causing habitat degradation by livestockgrazing, illegal collection of non-timber forest products and forest fires. The smallest Jorepokhri WLS, a wetland, is not a known tiger habitat. Teesta Valley $\left(54.14 \mathrm{~km}^{2}, 27^{\circ} 03^{\prime} 36.00^{\prime \prime} \mathrm{N}, 88^{\circ} 25^{\prime} 48.00^{\prime \prime E}\right)$ under Darjeeling Forest Division was another erstwhile habitat occupied by the tiger, which used to migrate in between the valley in Darjeeling and Sikkim or Kalimpong by conveniently crossing the intervening rivers. ${ }^{9}$

Similarly, Senchal WLS (Figure 3) is not the home of tiger nowa-days. However, the famous Tiger hill $\left(2,590 \mathrm{~m}, 27^{\circ} 00^{\prime} 0.00^{\prime \prime} \mathrm{N}\right.$, $\left.88^{\circ} 16^{\prime} 60.00^{\prime \prime} \mathrm{E}\right)$, a forest ridge located within Senchal, was formerly frequented by the tigers and, hence, so named. ${ }^{6}$ Before independence, the surrounding tea estate managers used the government forests as a game reserve to hunt tigers and leopards. Around 33 villages are present in and around the PA. These villages occur as Khasmahal areas or forest villages or tea estates. Hence, biotic pressures on this natural forest like cattle grazing, collection of fuel-wood and extraction of timber as well as slash-and-burn practices caused an irreversible change to this habitat.

On the contrary, the east-west ecological range of terai landscape south of Senchal is known to sustain the tiger population in Darjeeling district. Here, the forests consist of sal and its associates with patches of grassland and acacias on the sandy riverine areas. Cane brakes, elephant grass and reeds abound on moist areas, which are attractive habitats for the prey species like deer, pigs, etc. This region is traditionally the most favourite hunting ground of the tiger. These conditions were found in central and eastern portions of the Mahananda WLS (Figure 4), comprising of Gulma valley, Choklong, Silibhita and lower Ghoramara. Even during early $20^{\text {th }}$ century, the riverine grassland of Gulma was a popular tiger-hunting ground. A population of 15-16 tigers was reported during last century from about $60 \%$ forests of the PA. ${ }^{2}$ Pug-marks were seen on the river-bed. But, for many years, no sighting record is reported from Mahananda.

From the frequency of foot prints seen, it was observed that the tiger mainly concentrates in the eastern and central portions in Mahananda. Stray cases of Sambar and Chital killed by tiger had occasionally been detected here. On the contrary, the favourite alluvial savanna grasslands of this region have been declining, resulting in reduction in prey as well as predator populations.

Conversion of the higher hills around Latpanchor into tea estates and cinchona plantations has fragmented the ecological boundary of Mahananda. Population pressures have increased in this area over years. 11 forest villages, many tea garden settlements and revenue villages are present in and around the protected area. Illegal fuelwood collection and timber cutting, cattle herding, encroachment of the farmlands, etc. are causing habitat degradation in the PA and only a few undisturbed patches are left. Due to substantial clearing toward peripheral areas, the surrounding landscape has become increasingly fragmented, with serious impact on the wildlife corridor (Length: 10 $11 \mathrm{~km}$; width: $3 \mathrm{~km}$ ) in between Mahananda and Baikunthapur forests.

In the past tiger population in Kurseong Forest Division was distributed in the forest blocks contiguous to Mahananda like Lohargarh $\left(6.92 \mathrm{~km}^{2}\right)$, Bamanpokhri including Balason, Lamagumba and Pankhabari $\left(20.33 \mathrm{~km}^{2}\right),{ }^{2}$ where the habitat was dotted with grassland and shrubs and bushes. Lastly, Bagdogra $\left(15 \mathrm{~km}^{2}\right.$, $26^{\circ} 42^{\prime} \mathrm{N} 88^{\circ} 19^{\prime} \mathrm{E}$ ) under Kurseong Forest Division, $40 \mathrm{~km}$ south of Mahananda, was so named because the place was infested with tigers even during early $20^{\text {th }}$ century. ${ }^{6}$ The fragmented Kurseong Forest Division has no recent record of the tiger.

To the east of Mahananda, a straying tigress was seen at the Apalchand forests under Baikunthapur Forest Division, which has a link (connecting corridor) with Mahananda. Baikunthapur is also not home of the tiger. In the past, only loners were seen in Jalpaiguri Forest Division. There are no recent sighting records from this Division. From the left bank of Teesta to the Khairbari forest on the east, no tiger was there due to poaching. ${ }^{1}$

In Gorumara NP (Figure 5), the terai grassland is interspersed with riverine forests, dry mixed forests, wet mixed forests and sal forests. Flood plains of the rivers Jaldhaka and Murti include tall riparian grassland of Phragmitis, Alpinia, Typha etc. The riverine grassland and Savannah woodland occupied about $20 \%$ of the total plant cover of Gorumara, which was the grazing-cum-foraging ground of the wild herbivores and the tiger. A couple of tiger was reported in this PA during 1990s. ${ }^{10}$ But, now that the riverine grassland and savannah woodland has reduced to about $10 \%$ of total plant cover of the Park and the anthropogenic pressure has been multiplied in this region. There are 13 revenue villages, four forest villages and five tea estates 
just outside the Park. The people residing there depend on the Park for fuel wood and fodder and exert tremendous anthropogenic pressure on the forest resources. Consequently, the resident tiger population moved northwards to the safe and undisturbed habitat with a high prey-base in the upper Neora Valley NP during late 1980s. Last in April 2009, a forest guard spotted an adult tigress and her cubs in the riverine grassland on the north of Gorumara. Now, Gorumara is not home to any resident population of the tiger. Similarly, tigers are absent in Chapramari WLS.

In Kalimpong district, only Neora Valley (Figure 6) is now the most viable habitat of the tiger. ${ }^{11}$ Its movement during FebruaryMarch along the River Neora up to an altitude of 2,300m in Rachila Block (starting from Rachilla Chawk, below the Rachilla Danda), the highest place at the tri-junction of Bhutan, Sikkim and Bengal, was reported in the $9^{\text {th }}$ Working Plans of the Kalimpong Forest Division (1997-98 to 2017-18). Neora has four main habitat types: Subtropical Mixed Broadleaf Forest, Lower Temperate Evergreen Forest, Upper Temperate Mixed Broadleaf Forest and Rhododendron Forest. In 1998, faecal samples of 13 tigers were found in Neora. Thereafter, a monitoring team traced pug-mark of an adult male in Rachila $(3,150 \mathrm{~m})$ area in April 2016. During field visit in this block, a hunting spot was seen in compartment 13 of Rachila block $\left(27^{\circ} 06^{\prime} \mathrm{N}, 88^{\circ} 45^{\prime} \mathrm{E}\right)$, where a tiger had killed approximately a $35 \mathrm{~kg}$ ungulate species a few days ago. The temperate forest here represents a dense canopy and thick undergrowth of Quercus-Lithocarpus-Yushania-Rhododendron.

Two dozen cameras had been installed at several heights in strategic locations, ranging between $2,100 \mathrm{~m}$ and $2,400 \mathrm{~m}$, just before the arrival of winter because it was anticipated that during winter they descend from the higher altitudes of the park or from the adjoining forests of contiguous Bhutan and Sikkim to the lower heights of Neora Valley. On $27^{\text {th }}$ December 2018, at about 6-7 pm 4-5, four of these cameras, installed in between Rechila and Pankhasari, captured 4-5 images of tiger. Recently, three tiger images were camera-trapped at three different times of the day in three different areas (located near Rachila) of Neora Valley in January-February 2017. Reportedly, a tiger had also been spotted while drinking water and photographed on 19 January 2017 by a cab-driver at Rishap on the north-western fringes of Neora Valley on his way from Pedong to Lava. Again, another tiger was reportedly seen by a cab-driver to cross the road near Samsing tea estate on the north-eastern flank of Neora. Its pug mark was also traced and confirmed to be that of a tiger by the forest department staff.

Till the late 1980 s, tigers were known to migrate to high-altitude forests from Neora Valley to neighbouring Pangolakha WLS, Sikkim $\left(128 \mathrm{~km}^{2}, 27^{\circ} 32^{\prime} \mathrm{N}-27^{\circ} 35^{\prime} \mathrm{N}, 88^{\circ} 76^{\prime} \mathrm{E}-88^{\circ} 79^{\prime} \mathrm{E}\right)$. "Tigers in Sikkim are seasonal migrators from Neora Valley," said ML Srivastava, Secretary-cum-Principal Chief Conservator of Forests of the State in his interview (Down to Earth: 27 March 2019). Hathichirey (the place where elephants can penetrate) forms the tri-junction of Bhutan, Sikkim and West Bengal. Further down, the Pangolakha forest continues as a biological corridor with Neora Valley. In addition, such a corridor connecting Neora Valley and Toorsa Strict Nature Reserve $\left(169 \mathrm{~km}^{2}\right)$ of Bhutan is comprised of pristine forest areas and is uninhabited by human settlements. Migration of tiger along this corridor is also recorded. ${ }^{1}$

Presence of pugmarks, scats, leftovers of prey were indicative of presence of around 13 tigers at the park. Also, people residing on the fringes have reported hearing roars of the tiger. In recent times, tiger has been sighted only in Neora Valley. Hence, the pristine Neora Valley is considered as the most sensitive tiger conservation zone in the region. Due to inaccessibility and difficult terrain, the biotic pressures are not very acute in this PA. Human pressure is limited to some external threats associated with the tea and Cinchona plantations. Moreover, it is the least explored protected areas in the region. Due to all these congenial factors, it has become the most favourite habitat of the tiger in northern West Bengal. Straying tigers were recorded from Ramshai, Panjhora, Moraghat and Nathua blocks of Jalpaiguri Forest Division during the $20^{\text {th }}$ century. ${ }^{2}$ No record of tiger is available during last one decade in this Division.

Jaldapara NP (Figure 7), the prime rhino-land in the state located in the flood plains of the River Torsa and other small rivers, also provides excellent habitat for the tiger. Both food and cover are adequately available for this large carnivore. Jaldapara has pure grassland extending over $30.55 \mathrm{~km}^{2}$, which is the important habitat of Rhino, Hog Deer, Spotted Deer, Barking Deer, Elephant and Gaur. They preferred the open grassland with good water sources, avoiding the dense savannah forests. Hence, they were concentrated in Malangi, Jaldapara, Torsa and Chilapta blocks. They also used this grassland as the hunting ground. Sometimes tiger killed the calves of rhino if they were unprotected and detached from their mother. During $20^{\text {th }}$ century, there was a population not exceeding a dozen. Presence of six tigers was recorded in 2004 census. ${ }^{2}$ Hunting, poaching, train accident and lack of breeding female tiger are the reasons for its decimation. There are no recent sighting records of tiger in Jaldapara. The fringe areas of Jaldapara are occupied by villages with dense forest-dependent human population. Illegal grazing by domestic livestock, regular collection of fuel wood and thatch grass are the major problems. Consequently, these resources have been largely depleted from the surrounding area.

In Koch Behar, tiger was found in the Patlakhawa Game Reserve $\left(16.48 \mathrm{~km}^{2}, 26^{\circ} 51^{\prime} \mathrm{N}, 89^{\circ} 34^{\prime} \mathrm{E}\right)$ of the Koch dynasty, contiguous to Jaldapara. ${ }^{2}$ Like his predecessors, Maharaja Jagaddipendra Narayan of Koch Behar (ruled since 1936) used to hunt along with the Maharajas of Jaipur, Nepal and Deoyas and other high officials of Indian Government in the protected forest areas of Patlakhawa, Takoamari, Gorpad, Bhalka, Shalbari for Royal Bengal Tiger, inter alia. The tiger population in Koch Behar was extirpated due to such royal hunting and loss of habitat before independence. In the same way, the small tiger populations were extirpated from the Barind tract (Malda and Dinajpur) during $20^{\text {th }}$ century due to massive deforestation, i.e. clearing of thorny bush jungle, locally known as 'Katal'. ${ }^{1}$ Its presence was last reported in these two districts. ${ }^{12}$

In BTR, the riverine grasslands and savannah woodlands occupied a considerable part of $51.31 \mathrm{~km}^{2}$, which offered a preferred grazing ground for Cheetal, Sambar, Barking Deer, Hog Deer, Gaur and Elephant. When Yusuf Salahuddin Ahmad (IFS) was the Divisional Forest Officer of Buxa Forest Division during 1939-42, the two eastern ranges, Rydak and Sankos, were particularly suitable for shooting tiger. ${ }^{2}$ The tigers frequently moved from one area to another and could always be put up for the shoot.

In fact, large-scale imperial hunting had extirpated the most flourishing tiger population from this grassland habitat of Buxa, then the largest one in north Bengal. Rydak was largely a tree forest but along the bank of the river Rydak on the east there were these patches of grassland, which could be beaten for the tiger. There were cane 
breaks on the south interspersed by smaller rivers, which were also good habitats for the tiger. Hence, VIP-shoots were mostly organized in Buxa Division. A $285 \mathrm{~cm}$ tiger was also shot in this forest.

Tiger habitat is not uniformly distributed in BTR (Figure 8). During the present study, it was observed that $147.26 \mathrm{~km}^{2}$ (Reserve Forests of Chunabhati, Dhawla, Godamdabri, Gadadhar, North Bholka, Narathali, Rangamati, South Bholka and Tobgaon blocks) or $19.35 \%$ of BTR in addition to $29.09 \mathrm{~km}^{2}$ (Protected and Unclassed
State Forests) or $2.77 \%$ of BTR (mostly buffer areas), were not occupied by any tiger. Besides, a small patch of upper ridges of Sinchula range (between 1,700 $\mathrm{m}$ and 1,800 m altitude) was not used by them as their habitat. Traces of tiger's presence were found in those habitats with high species diversity of prey animals (most preferredhog deer, sambhar, spotted deer; less preferred- wild boar, gaur, cattle; porcupine (not preferred). The smaller prey animals like goral, serow, hare, macaque, otter, rodents, squirrels, etc. are also consumed as and when available.

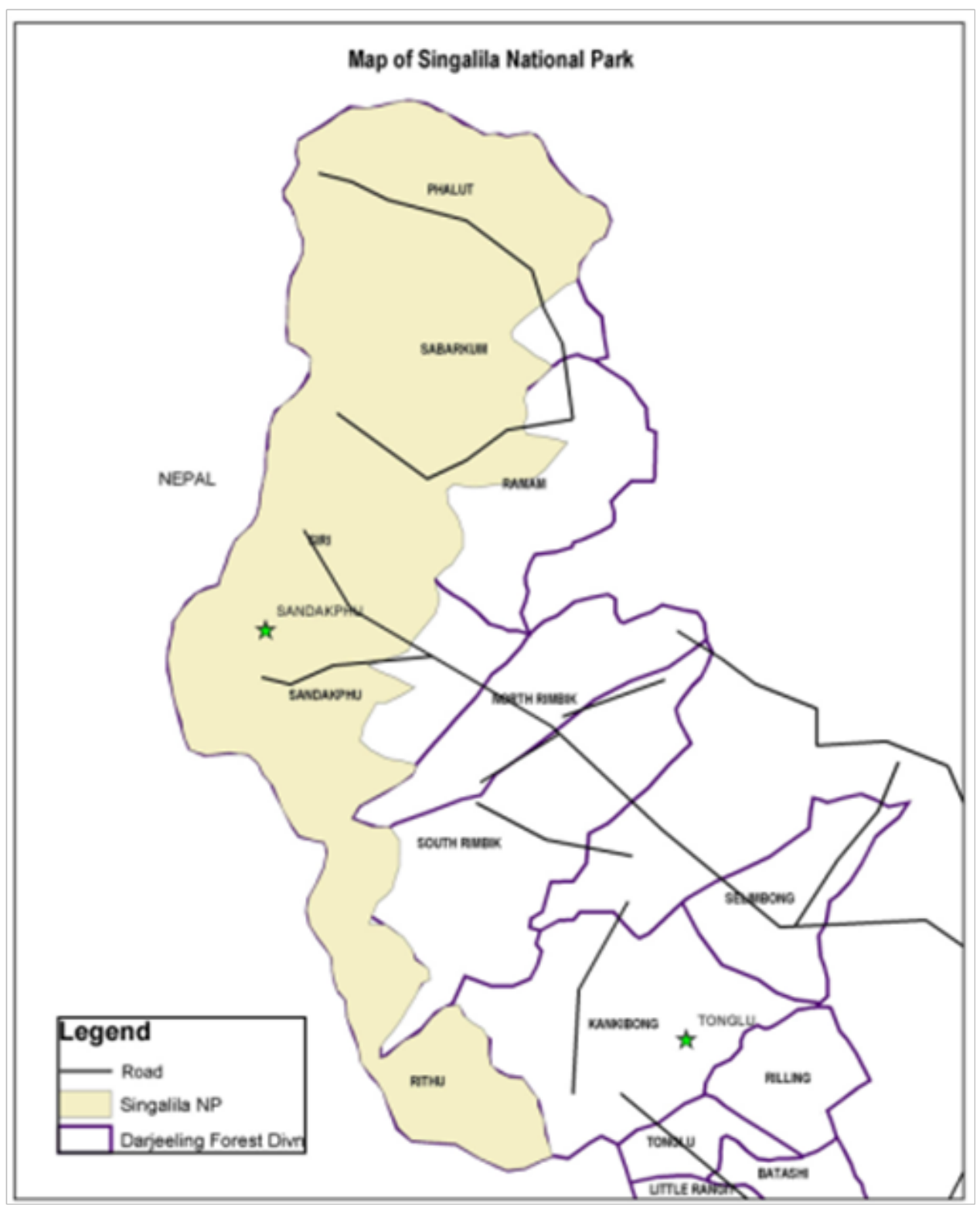

Figure 2 Map of Singalila National park. 


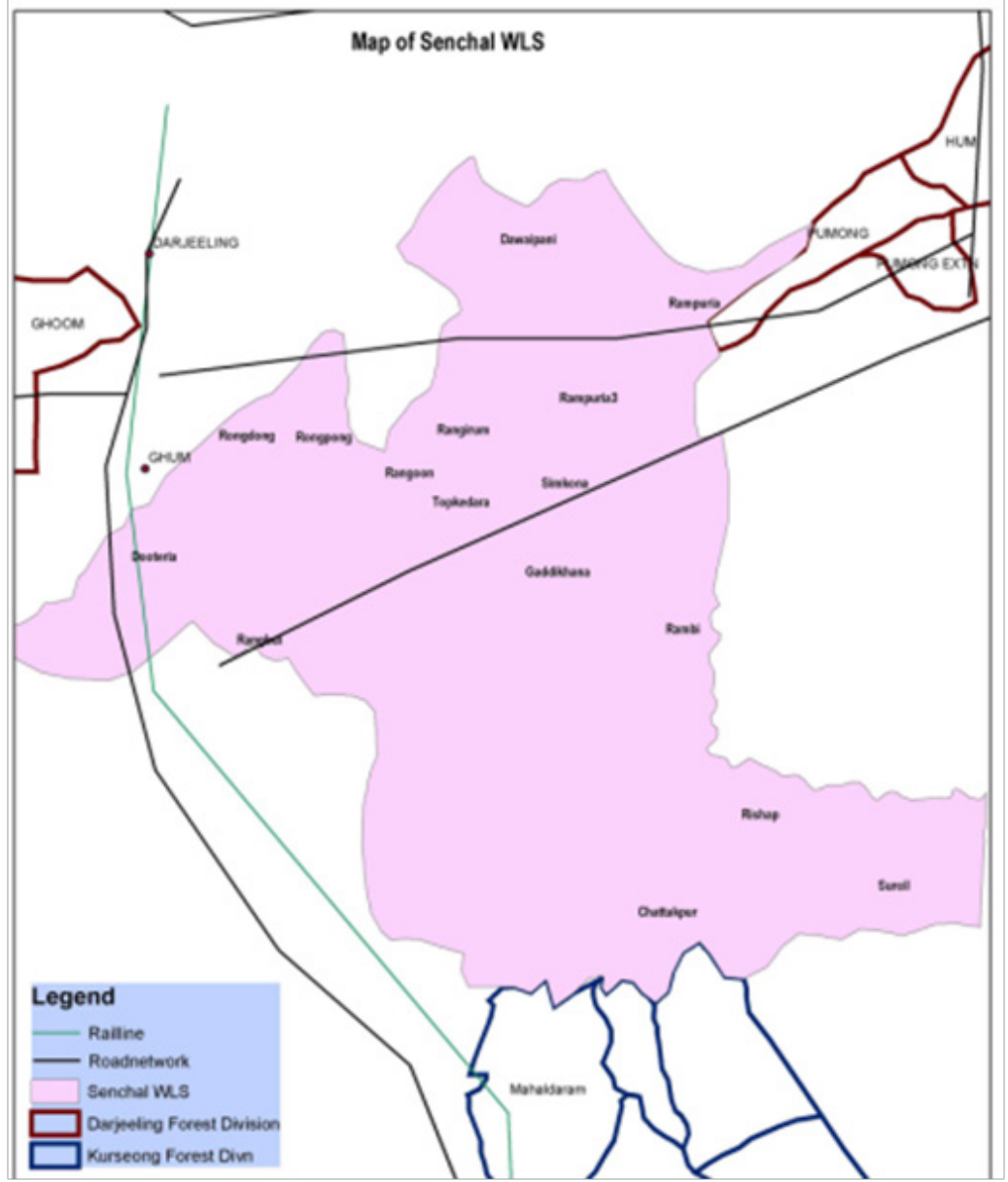

Figure 3 Map of Senchal WLS

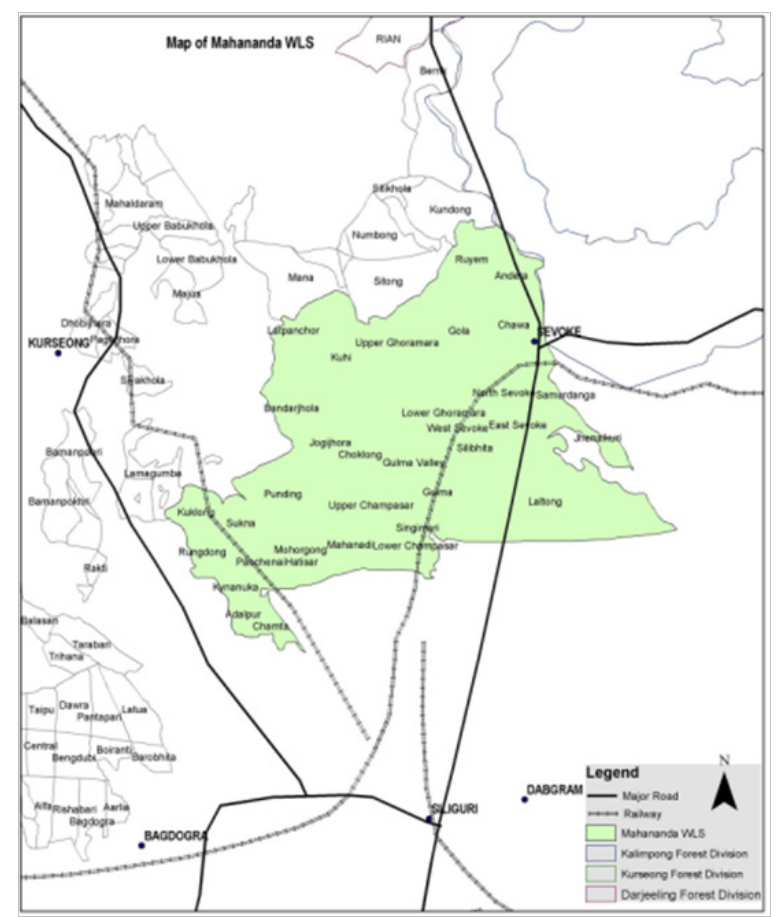

Figure 4 Map of Mahananda WLS.

Citation: Mallick JK. Panthera tigris: range and population collapse in Northern West Bengal, India. Biodiversity Int J. 20I 9;3(3): I I0-I I9. DOI: I0.I5406/bij.20I9.03.00I35 


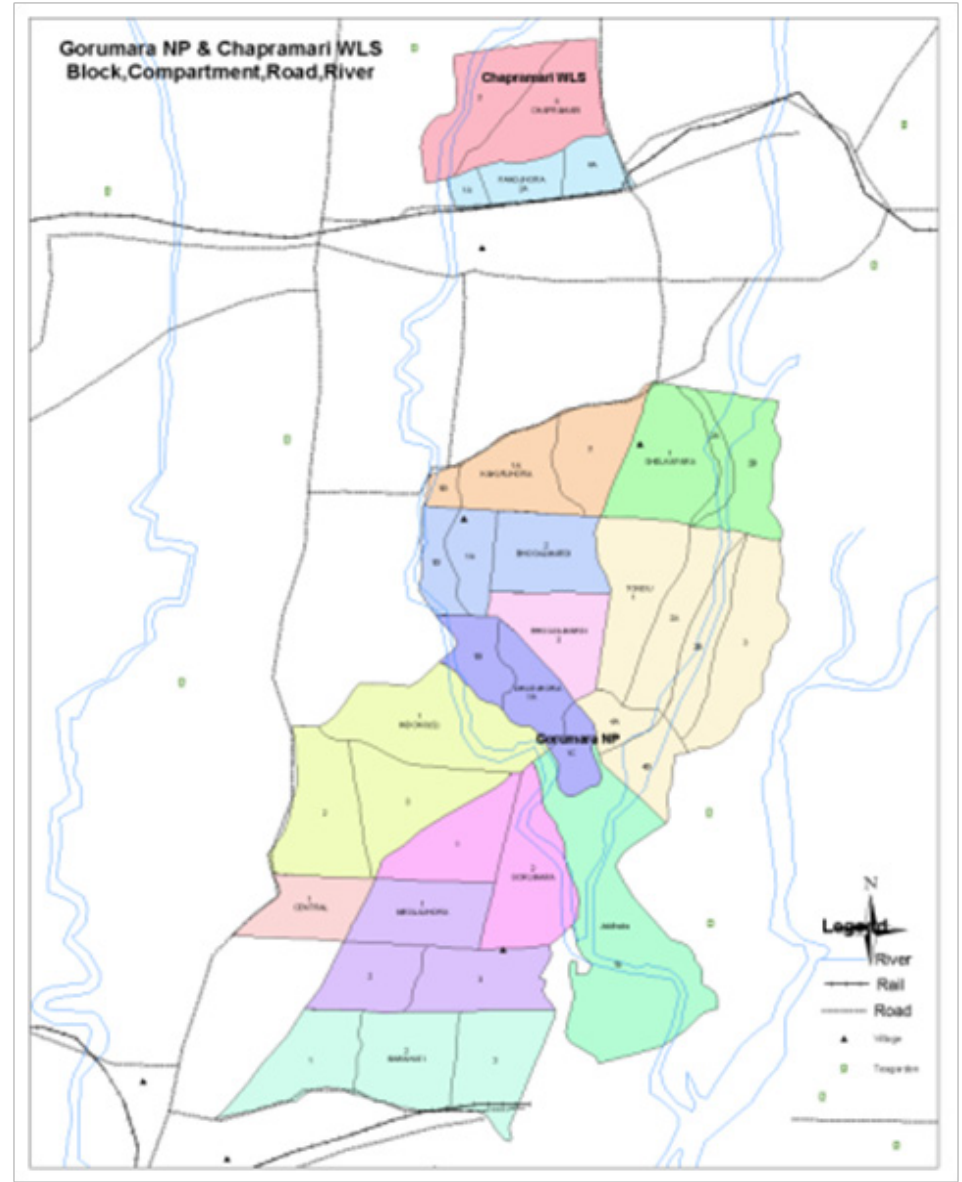

Figure 5 Gorumura NP \& Chapramari WLS.

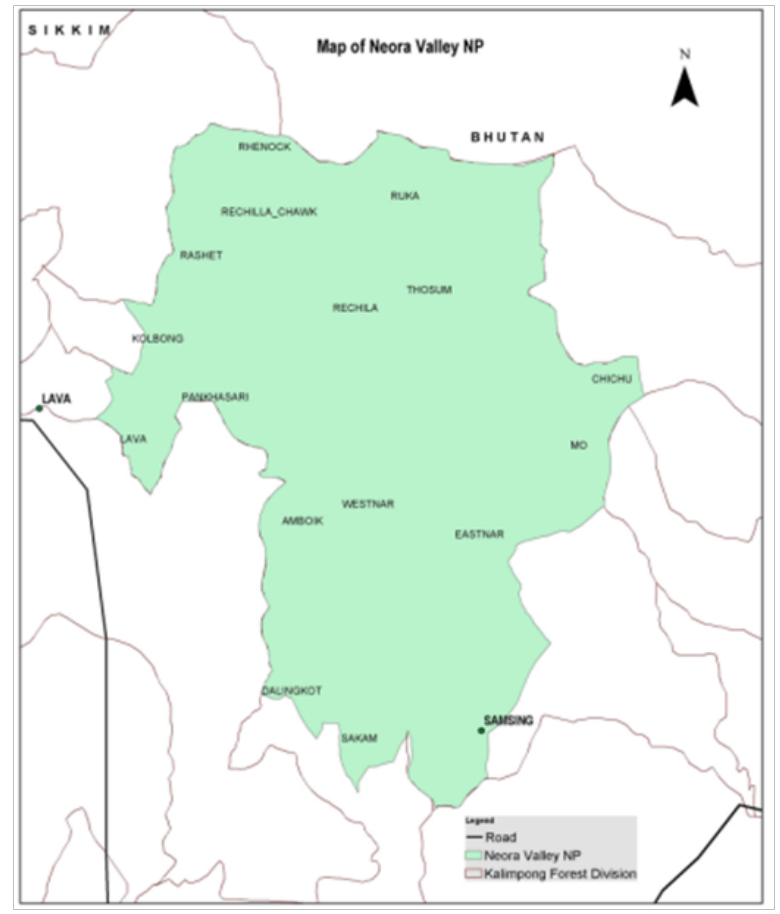

Figure 6 Map of Neora Valley NP. 


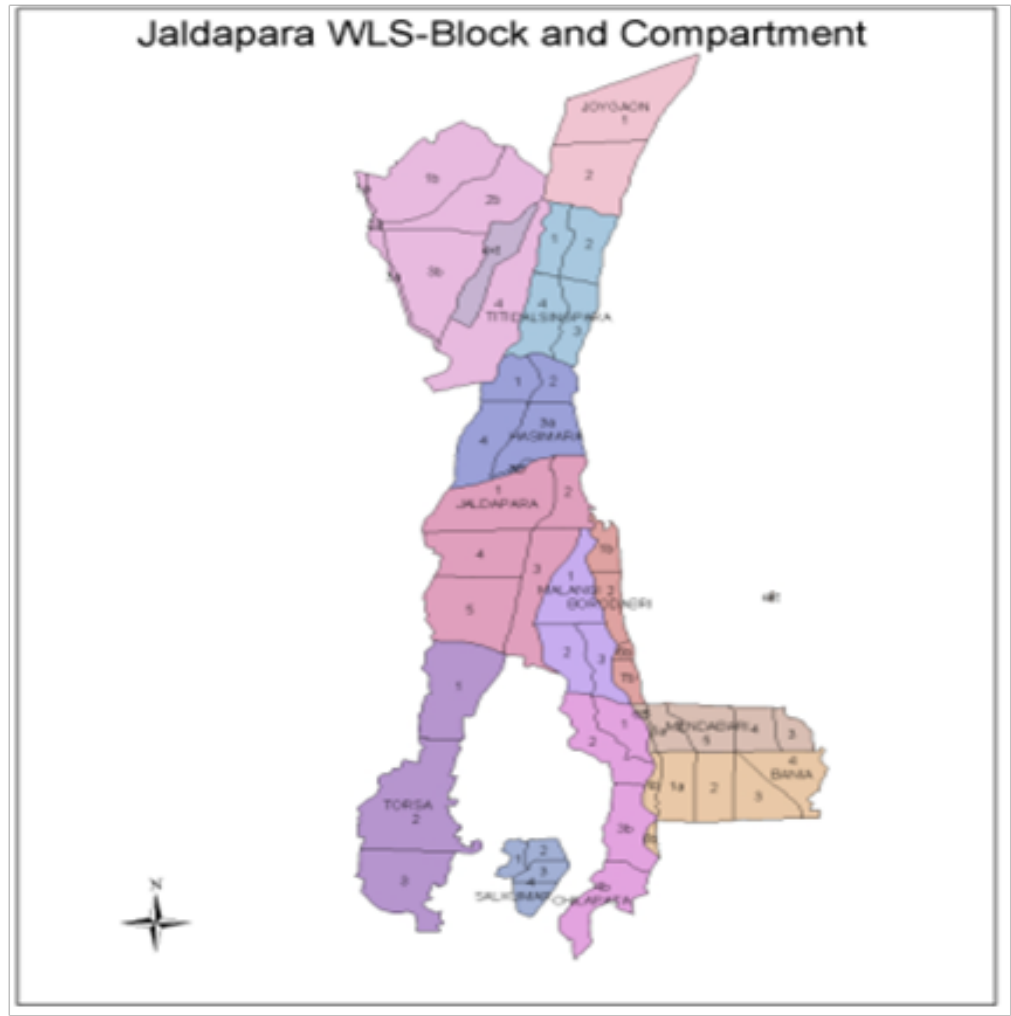

Figure 7 Jaldapara WLS.

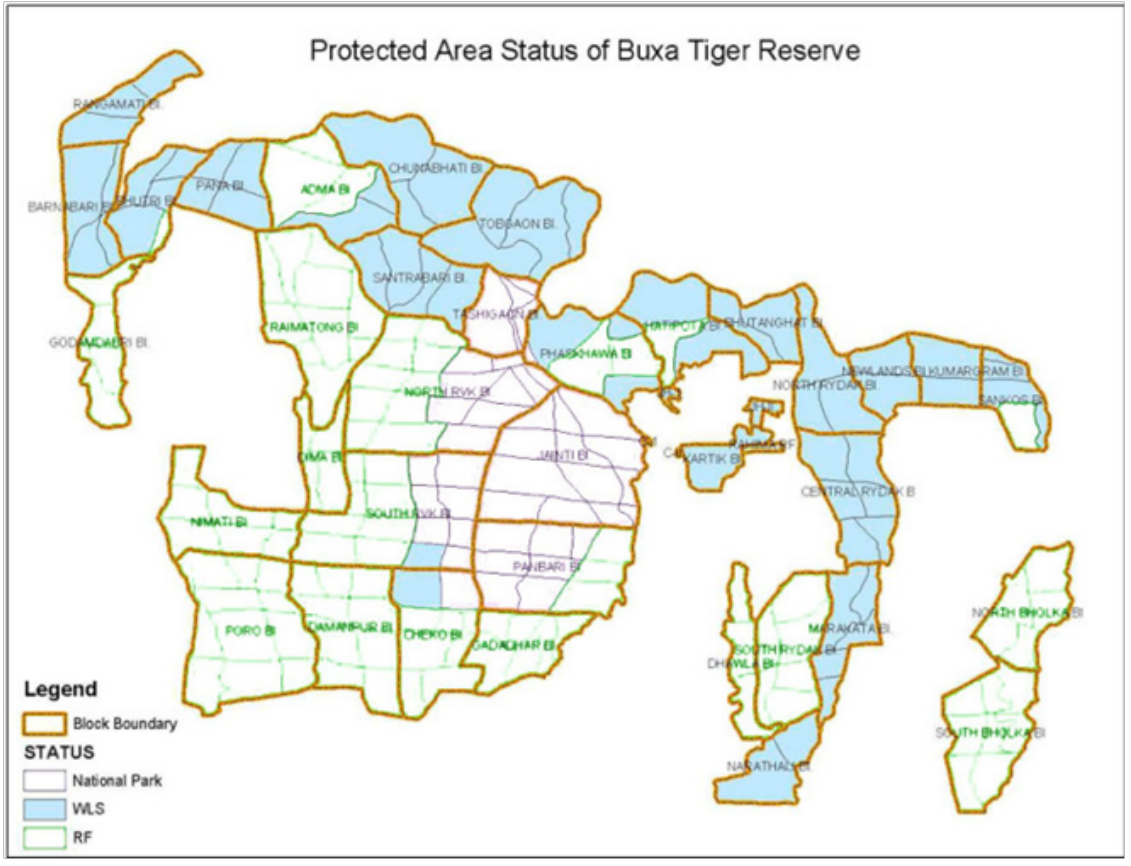

Figure 8 Protected area status of Buxa Tiger reserve. 
The present study has revealed that $205.55 \mathrm{~km}^{2}(27.01 \%$ of Reserve Forests in BTR, mostly the PAs like Jainti, North Rajabhatkhawa, Phaskhawa, Raimatang and South Rajabhatkhawa blocks), appears to be the prime habitat of tiger because those blocks have comparatively high diversity of prey species. It appears from the deer Habitat Occupancy Chart (HOC) that among the four species of deer found in BTR, Barking Deer is the most widespread species, covering $59.94 \mathrm{~km}^{2}$, i.e $7.87 \%$ of BTR, whereas the other three species are restricted, particularly the Hog deer, the obligate species of grassland, inhabiting only two eastern blocks over $34.86 \mathrm{~km}^{2}$, i.e only $4.58 \%$ of BTR. Cheetal is distributed over 11 blocks covering $302.55 \mathrm{~km}^{2}$, i.e. $39.76 \%$ of BTR, whereas Sambar inhabits six blocks over $217.17 \mathrm{~km}^{2}$, which is $28.54 \%$ of BTR. Wild boars are distributed more or less throughout BTR, particularly grassland or scanty bush jungle, sometimes in forest. A tigress usually selects a safe and undisturbed habitat for rearing the cubs. The sub-adult population, both male and female, on being territory-conscious and after being alienated from their mother, usually explore the forests on the east as well as on the west through dispersal in quest of food, shelter, etc. Some spots have indicated presence of more than one tiger, showing overlapping of territories, and the same number wandering over large area in order to meet its biological needs. The prey-density was very low in rest of BTR, at least during the last one decade or more to sustain a viable population of tiger. Earlier, a tiger (later named Joy), which could not even walk, was rescued near Jayanti and brought to Rajabhatkhawa Rescue Centre, where it was found to be hungry for quite some time and infected and treated successfully by the departmental veterinarian. ${ }^{1}$

Above all, Buxa has 37 forest villages and 4 fixed demand holdings, 46 revenue villages and 34 tea gardens in and around it. Forest land still remained under encroachment in BTR. Thus, BTR is under tremendous anthropogenic pressure, with nearly 0.2 million people living in the vicinity, along with their livestock (about one lakh). Large-scale cattle grazing (main on rotational basis in the buffer area), fuel-wood collection, timber-smuggling and others have also threatened this viable habitat of tiger and undermined tiger conservation efforts.

Based on genetic analysis of 372 confirmed faecal samples of tiger (collected during 2010-2013), the tiger habitats in BTR were classified approximately $62 \%$ of as suitable ( $21 \%$ moderately suitable, $23 \%$ suitable and only $17 \%$ highly suitable), but no data regarding the population in the sample locations were generated. ${ }^{13}$

In its analysis of scat samples sent by the forest department in 2013, the Wildlife Institute of India found signs of three tigers only. Whereas Aaranyak (Assam) found 14 tigers and Centre for Cellular and Molecular Biology (Hyderabad) found 15 tigers by genetically analysing samples of scat (or faeces) they had gathered in 2010, during the next year the former organization found 19 and the latter found 20 tigers. ${ }^{14,15}$ Such fluctuating population figures have led to question authenticity of such exercises. The riddle looms large since there has been no recent sighting of any tiger in Buxa like that of Neora. On 29 May 2013, one tiger was, however, sighted in between 25 and 26th Mile P.W.D. Road in Buxa.

The results of above mentioned DNA study (2013) also indicated possible movement of tigers from contiguous forest patches of Bhutan to the north and Manas Tiger Reserve on the east of Buxa. ${ }^{15}$ Faecal samples of one male tiger individual (M3) were found at the bordering areas of Buxa (first at North Rydak and thereafter North Bholka) and Ripu Chirang Reserve Forests (buffer of Manas TR,
Assam). Ripu and Chirang are vital habitats that serve as a corridor linking Manas with Buxa. Thus, there is a possibility of movement of tigers between Buxa and Manas. In addition, trans-boundary dispersal and exchange of genes of tiger between Phibsoo WLS ( $268.93 \mathrm{~km}^{2}$, $26^{\circ} 42^{\prime} \mathrm{N}-26^{\circ} 51^{\prime} \mathrm{N}, 89^{\circ} 56^{\prime} \mathrm{E}-90^{\circ} 12^{\prime} \mathrm{E}$ ) of southern Bhutan (having biological corridor linking Royal Manas) and contiguous northern BTR is also mentioned in the Tiger Action Plans of 13 Tiger Range Countries (2011) by Global Tiger Forum and National Tiger Survey of Bhutan (2014-2015). The forests of Ripu and Chirang are contiguous not only with those of BTR but also Phibsoo WLS of Bhutan.

\section{Conclusion}

The loss of habitat scarcity of prey animals and biotic disturbances are identified to be the most important factors leading to decimation of the tiger in the region. A Tiger Conservation Action Plan for North Bengal should be prepared and implemented. Development of institutional conservation capacity, ensuring effective patrolling force to prevent illegal activities like poaching or exploitation of natural resources, regular evaluation of occupancy, connectivity and size of tiger population, reduction of unsustainable use of forest resources. Promoting trans-boundary collaboration for conservation of tigers involving the concerned PA Managers of Assam, Sikkim and West Bengal in India and Bhutan should be ensured. Prioritized tiger conservation activities, based on existing knowledge, be carried out in phases followed by regular monitoring and evaluation.

\section{Acknowledgments}

The author is grateful to the field officers of Wildlife Wing, Forest Department, Government of West Bengal, for their help and cooperation during the study.

\section{Conflicts of interest}

The author declares that there is no conflict of interest.

\section{References}

1. Bahuguna NC, Mallick JK. Handbook of the mammals of South Asia with special emphasis on India, Bhutan and Bangladesh. Natraj Publishers, Dehradun. 2010.

2. Mallick JK. Past and present status of the Indian Tiger in northern West Bengal, India: an overview. Journal of Threatened Taxa. 2010;2(3):739952 .

3. Jhala YV, Gopal R, Qureshi Q. Status of tigers, co-predators and prey in India. 2008.

4. Jhala YV, Qureshi Q, Gopal R. The status of tigers in India 2014. National Tiger Conservation Authority, New Delhi \& The Wildlife Institute of India, Dehradun. 2015.

5. Jhala YV, Gopal R, Qureshi Q. Status of tigers, co-predators and prey in India. 2010.

6. O Malley LSS. Bengal District Gazeteers. Darjeeling. Logos Press, New Delhi, 1907;12-13.

7. Dutt Mazumdar S. Wildlife of Darjeeling Hills. Journal of Bengal Natural History Society. 1955;27(4):155-159.

8. Baldry TA. The Tonglu Tiger. Journal of the Darjeeling Natural History Society. 1923;1(2):80-82.

9. Yadav VK. The denizens of Darjeeling hills. Banabithi, Wildlife Issue, Kolkata. 2004;34-36. 
10. Pratihar S, Chakraborty S. An account of the mammalian fauna of Gorumara National Park, Jalpaiguri, West Bengal. Records of the Zoological Survey of India. 1996;95(3-4):229-241.

11. Mallick JK. Mammals of Kalimpong Hills, Darjeeling District, West Bengal, India. Journal of Threatened Taxa. 2012;4(12):3103-3136.

12. Baker EB. Sport in Bengal: How, When and Where to seek it. London: Ledger. 1887;1-368.

13. Sarkar MS, Segu H, Bhaskar JV, et al. Ecological preferences of large carnivores in remote, high-altitude protected areas: insights from Buxa Tiger Reserve, India. Oryx. 2018;52(1):66-77.
14. Borthakur U, Das C, Talukdar BK. Genetic assessment of the status of tigers in Buxa Tiger Reserve, West Bengal. Technical Report, Aaranyak. 2010;1-19.

15. Borthakur U, Saini RP, Sengupta S, et al. Noninvasive genetic assessment of population status of tigers (Panthera tigris tigris) in Buxa Tiger Reserve, West Bengal, India. International Journal of Biodiversity and Conservation. 2013;5(1):27-32. 